\title{
Carbon and Redox Tolerant Infiltrated Oxide Fuel-Electrodes for Solid Oxide Cells
}

Skafte, Theis Løye; Sudireddy, Bhaskar Reddy; Blennow, P.; Graves, Christopher R.

Published in:

E C S Transactions

Link to article, DOI:

10.1149/07207.0201ecst

Publication date:

2016

Document Version

Peer reviewed version

Link back to DTU Orbit

Citation (APA):

Skafte, T. L., Sudireddy, B. R., Blennow, P., \& Graves, C. R. (2016). Carbon and Redox Tolerant Infiltrated Oxide Fuel-Electrodes for Solid Oxide Cells. E C S Transactions, 72(7), 201-214.

https://doi.org/10.1149/07207.0201ecst

\section{General rights}

Copyright and moral rights for the publications made accessible in the public portal are retained by the authors and/or other copyright owners and it is a condition of accessing publications that users recognise and abide by the legal requirements associated with these rights.

- Users may download and print one copy of any publication from the public portal for the purpose of private study or research.

- You may not further distribute the material or use it for any profit-making activity or commercial gain

- You may freely distribute the URL identifying the publication in the public portal 


\title{
Carbon and Redox Tolerant Infiltrated Oxide Fuel-Electrodes for Solid Oxide Cells
}

\author{
T. L. Skafte, ${ }^{\mathrm{a}, \mathrm{b}}$, B. R. Sudireddy ${ }^{\mathrm{a}}$, P. Blennow ${ }^{\mathrm{a}, \mathrm{b}}$ and C. Graves ${ }^{\mathrm{a}}$ \\ ${ }^{a}$ Department of Energy Conversion and Storage, Technical University of Denmark, Risø \\ campus, Frederiksborgvej 399, 4000 Roskilde, Denmark \\ ${ }^{\mathrm{b}}$ Presently at Haldor Topsoe A/S, Haldor Topsøes Allé 1, 2800 Kgs. Lyngby, Denmark
}

To solve issues of coking and redox instability related to the presence of nickel in typical fuel electrodes in solid oxide cells, Gd-doped $\mathrm{CeO}_{2}(\mathrm{CGO})$ electrodes were studied using symmetric cells. These electrodes showed high electro-catalytic activity, but low electronic conductivity. When infiltrated with $\mathrm{Sr}_{0.99} \mathrm{Fe}_{0.75} \mathrm{Mo}_{0.25} \mathrm{O}_{3-\delta}$ (SFM), the electronic conductivity was enhanced. However, polarization resistance of the cells increased, suggesting that the infiltrated material is less electro-catalytically active and was partly blocking the CGO surface reaction sites. The activity could be regained by infiltrating nano-sized CGO or NiCGO on top of SFM, while still sustaining the high electronic conductivity. Ohmic resistance of the electrodes was thus practically eliminated and performance comparable to, or better than, state-of-the-art fuel electrodes was achieved. The $\mathrm{Ni}$ containing cells were damaged by carbon deposition in a $\mathrm{CO} / \mathrm{CO}_{2-}$ atmosphere, while none of the non-nickel cells catalyzed carbon. Stability towards redox cycles was also proven.

\section{Introduction}

Solid oxide cells show great potential as a means for energy conversion. The capability of high efficiency and scalability are among the distinct advantages of this technology. However, the use of steam and hydrogen in the cell is linked to issues that hinders commercialization in the near future (1). That is, employment of these gases on a large scale would require a restructuring of our current infrastructure and economy. Fortunately, these cells are capable of direct oxidation of hydrocarbons or of reformed gas mixtures, and electrolysis of $\mathrm{CO}_{2} / \mathrm{H}_{2} \mathrm{O}$ mixtures or $\mathrm{CO}_{2}$ for storage of electrical energy in the form of hydrocarbon fuels. Such involvement of hydrocarbons in the reactions would make the technology more suitable for our infrastructure. Hydrocarbons introduce additional challenges, however. The most commonly used fuel electro-catalyst, nickel, is also known for being an excellent carbon deposition catalyst (2). Carbon deposition within the electrode is highly unwanted as it limits the electrochemically active sites and in severe cases will ultimately lead to a catastrophic failure as the nickel containing fuel electrode delaminates from the electrolyte. The two main carbon deposition reactions are the Boudouard reaction, i.e. $\mathrm{CO}$ disproportionation, and methane cracking. Hence, an alternative catalyst or fuel electrode composition that does not catalyze carbon deposition could enlarge the possible operating window of the cells in hydrocarbon and $\mathrm{CO}$ containing fuel mixtures. 
In the present study, fuel electrodes mainly consisting of the mixed ionic and electronic conductor (MIEC) gadolinium doped ceria, $\mathrm{Ce}_{0.9} \mathrm{Gd}_{0.1} \mathrm{O}_{1.95}$ (CGO10) (3) are investigated. While this material has excellent electro-catalytic capabilities, it lacks sufficient electronic conductivity in reducing atmospheres. Therefore, another MIEC, the single perovskite strontium iron molybdenum oxide, $\mathrm{Sr}_{0.99} \mathrm{Fe}_{0.75} \mathrm{Mo}_{0.25} \mathrm{O}_{3-\delta}$ (here denoted SFM) (4-7), is infiltrated to serve as an electronic percolating network, as illustrated in Figure 1. The single perovskite is a more redox stable version (7) of the double perovskite, $\mathrm{Sr}_{2} \mathrm{FeMoO}_{6}(8-10)$. High conductivity $(200-300 \mathrm{~S} / \mathrm{cm})$ and power density have been reported for the latter (8-10), which is likely brought about by mixed-valences of $\mathrm{Fe}^{2+} / \mathrm{Fe}^{3+}$ and $\mathrm{Mo}^{5+} / \mathrm{Mo}^{6+}(4,11)$. One order of magnitude lower conductivity has been reported for the single perovskite $(6,11-13)$, but with the added benefit of redox stability. This is facilitated by increasing the Fe/Mo ratio to 2, thereby achieving the single perovskite structure (4), where $\mathrm{Fe}^{3+}$ and $\mathrm{Mo}^{6+}$ can co-exist when the material is oxidized. Excess oxygen vacancies and MIEC properties are obtained by subsequent reduction. However, it is suspected that covering the CGO backbone with SFM will reduce the catalytic activity of the electrode. A second infiltration step of $\mathrm{Ce}_{0.8} \mathrm{Gd}_{0.2} \mathrm{O}_{1.90}(\mathrm{CGO} 20)$ is attempted to regain the catalytic activity. The final electrode consists of only MIEC oxide materials with the CGO10 backbone supplying most of the ionic conduction, the infiltrated SFM most of the electronic conduction and the infiltrated CGO20 most of the electro-catalytic activity.

While relatively low polarization resistance has been reported for pure SFM electrodes, $0.15-0.35 \Omega \cdot \mathrm{cm}^{2}$ at $800{ }^{\circ} \mathrm{C}$ in dry hydrogen $(4-6,13)$, solid-state reactions between SFM and zirconia electrolytes (4) would be likely during long-term operation.

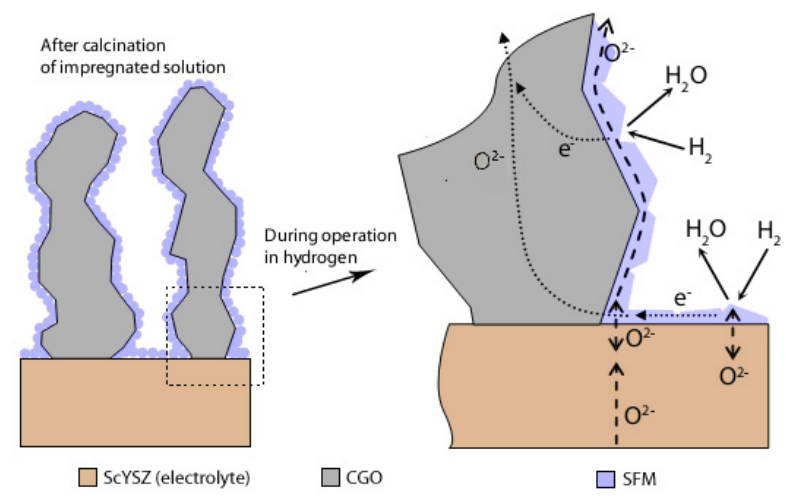

Figure 1. The MIEC material SFM infiltrated unto the CGO10 backbone, obtaining electronically and ionically conducting pathways. Here shown in a $\mathrm{H}_{2} / \mathrm{H}_{2} \mathrm{O}$ atmosphere without the additional infiltrated CGO layer on top of the SFM. Adapted from Blennow (14). 


\section{Experimental}

Cells

Several different types of symmetric electrochemical cells were prepared and tested. The CGO10 electrodes were hand-sprayed and sintered at $1200^{\circ} \mathrm{C}$ for $2 \mathrm{~h}$. Additionally, cells with a $2 \mu \mathrm{m}$ thick spin-coated CGO10 barrier layer (15) between the scandia- and yttria-stabilized zirconia (ScYSZ) electrolyte and the electrodes were also produced and sintered at $1150{ }^{\circ} \mathrm{C}$ for $2 \mathrm{~h}$ in air, before applying the electrodes. Composite SFM-CGO fuel electrodes were fabricated by infiltrating the porous CGO backbone with an aqueous precursor salt solution of SFM. Stoichiometric amounts of $\mathrm{Sr}\left(\mathrm{NO}_{3}\right)_{2}, \mathrm{Fe}\left(\mathrm{NO}_{3}\right)_{3} 9 \cdot \mathrm{H}_{2} \mathrm{O}$, $\left(\mathrm{NH}_{4}\right)_{6} \mathrm{Mo}_{7} \mathrm{O}_{24} 4 \cdot \mathrm{H}_{2} \mathrm{O}$, along with ethanol, citric acid and ethylene glycol were used in a ratio of metal-precursors:citric-acid:ethylene-glycol of 1:2:4. The ammonium molybdate tetrahydrate was added first and the strontium nitrate last, so as to avoid the preferential complexing of the cations. Infiltration steps were followed by a $0.5 \mathrm{~h}$ heat treatment at $400{ }^{\circ} \mathrm{C}$ to decompose the nitrates. This procedure was repeated multiple times, in order to obtain a loading of 10-16 vol-\% (estimated from electrode dimensions, weight gain per cycle and theoretical density of materials). Subsequently, the infiltrated cells were calcined at various temperatures ranging from $650{ }^{\circ} \mathrm{C}$ to $1100{ }^{\circ} \mathrm{C}$ for $2 \mathrm{~h}$. A few cells were also infiltrated with $\mathrm{SrMoO}_{3}(\mathrm{SM})$, following a similar procedure.

A number of cells were additionally infiltrated with $8-10$ vol\% CGO20 or NiCGO by following the same basic procedure, which is also described elsewhere (16). Infiltration steps were followed by a $0.5 \mathrm{~h}$ heat treatment at $350{ }^{\circ} \mathrm{C}$ and the final calcination was also done at $350{ }^{\circ} \mathrm{C}$ for $2 \mathrm{~h}$ to obtain the pure CGO phase.

An overview of the different types of cells and the notations with which they will be mentioned in this article can be seen in TABLE I. All types consisted of a $\sim 175 \mu \mathrm{m}$ thick ScYSZ electrolyte and porous 10-20 $\mu$ m CGO10 electrodes on both sides, with $60 \% \pm$ $4 \%$ porosity estimated from scanning electron microscopy (SEM) micrographs of polished epoxy-mounted cross-sections based on dark/light pixel ratio using the software ImageJ (17). Cells without barrier layers will be denoted " $Z$ ", and cells with barrier layers "CZC". The active area of the symmetric cells ranged from $0.25 \mathrm{~cm}^{2}$ to $0.35 \mathrm{~cm}^{2}$. The small active area of such cells introduces a possibility for error if not measured accurately. Therefore, measured resistance is corrected for the active area of each cell with a precision of $0.01 \mathrm{~mm}^{2}$ measured using an optical microscope.

TABLE I. A schematic overview of the tested cell types.

\begin{tabular}{|c|c|c|c|c|c|c|c|}
\hline Cell type ID & Z & SFM-Z & SFM-CZC & SM-CZC & CGO-SFM-Z & CGO-SFM-CZC & NiCGO-SFM-CZC \\
\hline Infiltrate \#2 & & & & & CGO & CGO & NiCGO \\
\hline Infiltrate \#1 & & SFM & SFM & SM & SFM & SFM & SFM \\
\hline Backbone & $\mathrm{CGO}$ & CGO & $\mathrm{CGO}$ & CGO & CGO & CGO & CGO \\
\hline Barrier layer & & & $\mathrm{CGO}$ & $\mathrm{CGO}$ & & $\mathrm{CGO}$ & $\mathrm{CGO}$ \\
\hline Electrolyte & ScYSZ & ScYSZ & ScYSZ & ScYSZ & ScYSZ & ScYSZ & ScYSZ \\
\hline Barrier layer & & & $\mathrm{CGO}$ & $\mathrm{CGO}$ & & $\mathrm{CGO}$ & $\mathrm{CGO}$ \\
\hline Backbone & $\mathrm{CGO}$ & $\mathrm{CGO}$ & $\mathrm{CGO}$ & $\mathrm{CGO}$ & $\mathrm{CGO}$ & $\mathrm{CGO}$ & $\mathrm{CGO}$ \\
\hline Infiltrate \#1 & & SFM & SFM & SM & SFM & SFM & SFM \\
\hline Infiltrate \#2 & & & & & $\mathrm{CGO}$ & $\mathrm{CGO}$ & NiCGO \\
\hline
\end{tabular}


Crystal structure, microstructure and other parameters

In order to check the phase formation using x-ray diffraction (XRD), the infiltration solutions of SFM were calcined at $250{ }^{\circ} \mathrm{C}$ for $\sim 12 \mathrm{~h}$. The powder was grinded and calcined again at various temperatures $\left(700-1100^{\circ} \mathrm{C}\right)$ for $5 \mathrm{~h}$ in air. Phase purity was checked using XRD (Bruker D8, Germany) using a $\mathrm{Cu}-\mathrm{k} \alpha$ radiation. The software Bruker Diffrac Plus Eva (18) was used to analyze spectra.

Dense pellets of phase pure, calcined SFM powder were made by uniaxial pressing and 60 ton isostatic pressing. The thermal expansion coefficient was determined using a Dilatometer DIL $402 \mathrm{C}$ on the pellets with an air flow of $50 \mathrm{~mL} / \mathrm{min}$ from ambient temperature to $1400{ }^{\circ} \mathrm{C}$ with a $10{ }^{\circ} \mathrm{C} / \mathrm{min}$ ramp rate.

Electrical conductivity was measured on pellets sintered at $1400{ }^{\circ} \mathrm{C}$. The measurements were performed in air up to $850^{\circ} \mathrm{C}$ using a custom 4-point Van der Pauw DC setup.

For SEM micrographs a Zeiss Supra 35 microscope with a field emission gun was used on metallographically polished samples mounted in epoxy.

\section{Electrochemical testing}

For electrochemical testing a fully automated in-house-designed (DTU Energy) 4symmetric-cell setup was used, as described elsewhere (19). Platinum current collection layer, platinum meshes and platinum wires were used. The cells were heated in air to 650 ${ }^{\circ} \mathrm{C}$ with $100{ }^{\circ} \mathrm{C} / \mathrm{h}$ and various test profiles were used to test the performance of the cells in a variety of temperatures and $p \mathrm{H}_{2} / p \mathrm{H}_{2} \mathrm{O}$ mixtures ranging from $0.03 / 0.97$ to $0.70 / 0.30$. The $\mathrm{H}_{2} / \mathrm{H}_{2} \mathrm{O}$ mixtures gave a range of oxygen partial pressures $\left(p \mathrm{O}_{2}\right)$ from $10^{-22}$ to $10^{-19}$ atm. $\mathrm{H}_{2}$ and $\mathrm{O}_{2}$ were combusted inside the inlet alumina tube to generate steam. $\mathrm{CO}$ and $\mathrm{CO}_{2}$ were directly mixed. Electrochemical impedance spectroscopy (EIS) measurements were performed using a Solartron 1260 Gain-phase impedance analyzer with 12 measurements per decade, typically in the frequency range $0.03 \mathrm{~Hz}$ to $0.9654 \mathrm{MHz}$ with an AC excitation amplitude of $33 \mathrm{mV}$. All EIS plots are recorded under open-circuitvoltage. Total flow rates were in the range of $2-6 \mathrm{~nL} / \mathrm{h}$. All EIS measurements were done at a stabilized $p \mathrm{O}_{2}$ and temperature.

Unless explicitly stated, the following spectra have been corrected for ohmic resistance from the test set-up, $\mathrm{R}_{\mathrm{aux}}$ (wires, contacts, cables), stray inductance by means of the Kramers-Krönig transforms and the data has been fitted using a complex nonlinear least squares routine with the equivalent circuit $R_{s}-L-R Q-R Q-R Q$ (20). A representative example of the impedance and the fitting can be seen in Figure 2. This simplified equivalent circuit was used as the present study only deals with the ohmic resistance $\left(R_{s}\right)$ and the polarization resistance $\left(R_{p}\right)$ so each individual process or circuit element is not investigated in detail. In this article $R_{p}$ refers throughout to the polarization resistance of a single electrode. 

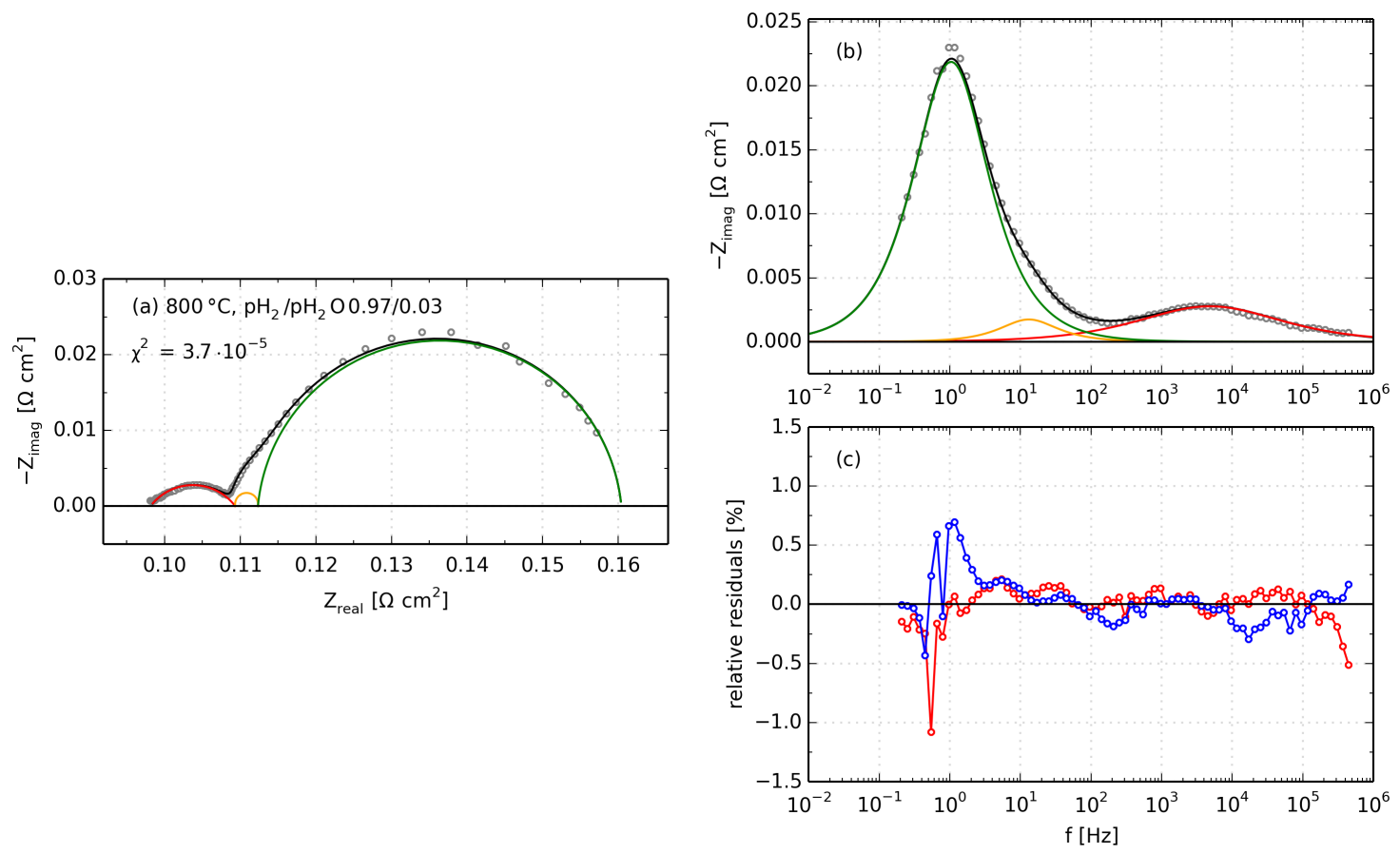

Figure 2. An example of a typical impedance plot and the equivalent circuit used for fitting the data. (a) Nyquist plot, (b) Bode plot and (c) relative residuals of the linearized Kramers-Krönig test.

Furthermore, all of the following data has been reproduced between at least two cells, unless explicitly mentioned. The data for each cell type has been chosen as a representative of that specific type, as the variations (number of infiltration cycles, calcination temperature) does not appear to influence the performance by a high degree, as will be discussed in the following.

\section{Results and discussion}

$\underline{\text { Preliminary material investigations }}$

Crystal structure. SFM powder was calcined in air at different temperatures and the XRD spectra can be seen in Figure 3a. The pure perovskite structure without impurities is only observed at $1100^{\circ} \mathrm{C}$, whereas at lower temperatures a lot of different impurities emerge. Noteworthy is the main peak for $\mathrm{SrMoO}_{4}$. This phase is virtually electronically insulating, but upon reduction to $\mathrm{SrMoO}_{3}(\mathrm{SM})$, the electronic conductivity surges to $2000 \mathrm{~S} / \mathrm{cm}$ (10). Other impurity phases are present, but not indexed. The secondary phases are not expected to be detrimental for the electronic conduction, and in the case of SM may even be beneficial.

Phase pure SFM powder (i.e. calcined at $1100{ }^{\circ} \mathrm{C}$ ) was also reduced at different temperatures in a dry atmosphere of $9 \% \mathrm{H}_{2}$ in $\mathrm{N}_{2}$, as seen in Figure $3 \mathrm{~b}$. It is seen that the SM impurity is observed for all temperatures, but most markedly at high temperatures 
$\left(850^{\circ} \mathrm{C}\right)$. Thus, regardless of calcination temperature, a small amount of SM is formed upon exposure to reducing environments. Phase stability after exposure to $\mathrm{H}_{2}$ at $1400{ }^{\circ} \mathrm{C}$ for $24 \mathrm{~h}$ has been reported (4), contrary to what is found in this study.
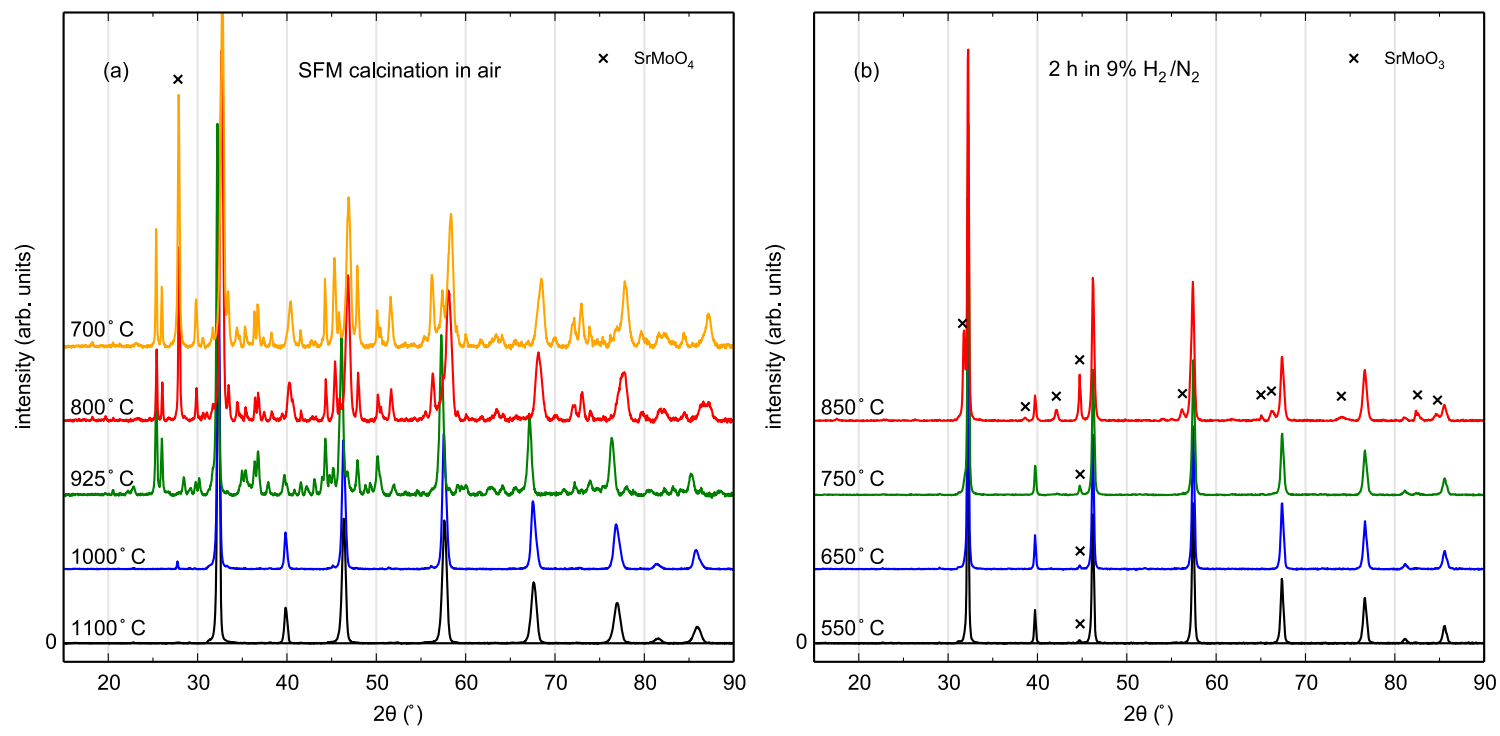

Figure 3. XRD spectra of (a) SFM powder after calcination at various temperatures in air, and (b) phase pure SFM powder after a $2 \mathrm{~h}$ reduction in $9 \% \mathrm{H}_{2}$ in $\mathrm{N}_{2}$ at various temperatures.

Thermal expansion and conductivity. The thermal expansion coefficient of phase pure SFM was determined by means of dilatometry as approximately $11.0 \cdot 10^{-6} \mathrm{~K}^{-1}$ in the temperature range $150-1400^{\circ} \mathrm{C}$, making it highly suitable for use with other typical solid oxide cell materials. However, higher values of $14.5 \cdot 10^{-6} \mathrm{~K}^{-1}\left(200-760{ }^{\circ} \mathrm{C}\right)$ and $20.9 \cdot 10^{-6} \mathrm{~K}^{-1}$ have been reported in literature $(11,21)$. Electronic conductivity was found to agree with literature, namely between $15 \mathrm{~S} / \mathrm{cm}$ (12) and $22 \mathrm{~S} / \mathrm{cm}$ (11) in the 500$800{ }^{\circ} \mathrm{C}$ temperature range, while similar values in reducing conditions have been reported, $13 \mathrm{~S} / \mathrm{cm}$ (13) and $33 \mathrm{~S} / \mathrm{cm}$ (6).

\section{Electrochemical testing}

Initial performance. Impedance spectra from the first couple of hours were analyzed to directly compare performance of the different cell types. A decrease in $R_{p}$ of the SFM infiltrated cells is observed by keeping the calcination temperature of the infiltrated material below $1100{ }^{\circ} \mathrm{C}$, as seen in the Nyquist and Bode plot in Figure 4, where $\mathrm{R}_{\mathrm{s}}$ have been subtracted to clearly illustrate differences in $R_{p}$. The high frequency arc (200-1000 $\mathrm{Hz}$ ) has increased drastically at the higher calcination temperature of $1100{ }^{\circ} \mathrm{C}$. Below a calcination temperature of $1100^{\circ} \mathrm{C}$, this second process is considerably suppressed, and $\mathrm{R}_{\mathrm{p}}$ is similar in magnitude. Ohmic resistance did not vary significantly for the different calcination temperatures. The lower calcination temperature will result in higher surface area of the nano-particles, which can partly explain the lower polarization resistance, but as the cell calcined at $800^{\circ} \mathrm{C}$ has a larger $\mathrm{R}_{\mathrm{p}}$, this is not the whole story. It can be 
speculated that the secondary phases formed at calcination temperatures below $1100{ }^{\circ} \mathrm{C}$ are also beneficial for the electrochemical reactions. In all the results presented hereafter, cells infiltrated with SFM were calcined at $800{ }^{\circ} \mathrm{C}$ or $900{ }^{\circ} \mathrm{C}$.
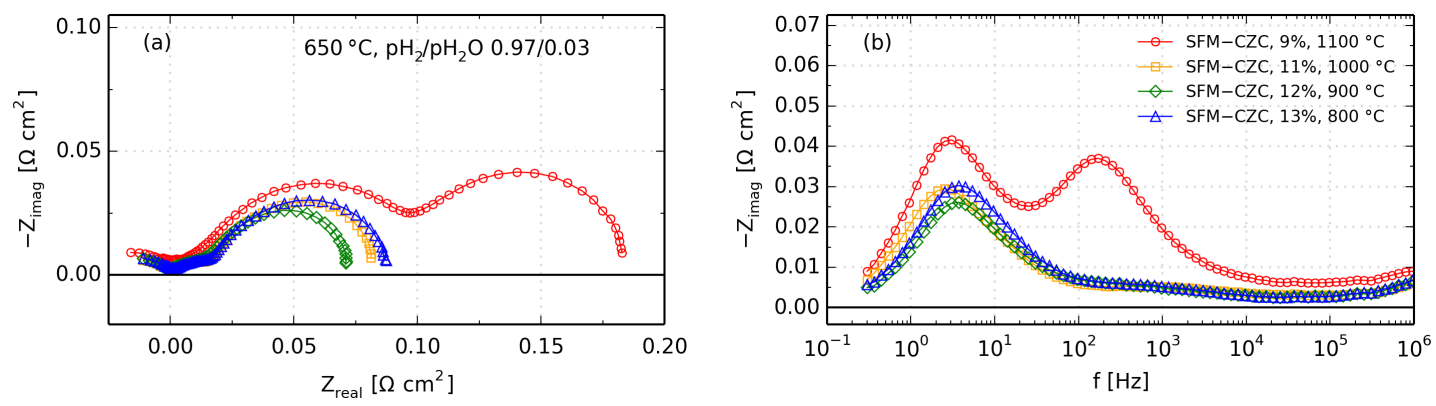

Figure 4. EIS data showing a comparison of different calcination temperatures of SFM. The approximate $R_{S}$ value has been subtracted and the symmetric cell data has been divided by 2 to ease comparison of $R_{p}$. Percentages and temperatures in the legend describe the approximate amount of infiltrated material in vol- $\%$ and the calcination temperature, respectively.

Infiltration of CGO or NiCGO after having infiltrated SFM lowered the $\mathrm{R}_{\mathrm{p}}$, as seen in Figure 5. It is also seen in Figure 5 that the amount of infiltrated NiCGO does not play a significant role in $\mathrm{R}_{\mathrm{p}}$. Since the purpose of the cell design was to avoid $\mathrm{Ni}$, it is promising that $\mathrm{CGO}$ and NiCGO surfaces show similar $\mathrm{R}_{\mathrm{p}}$, indicating that the $\mathrm{Ni}$ in NiCGO does not appear to play a role for the initial performance in $\mathrm{a}_{2} / \mathrm{H}_{2} \mathrm{O}$ atmosphere.
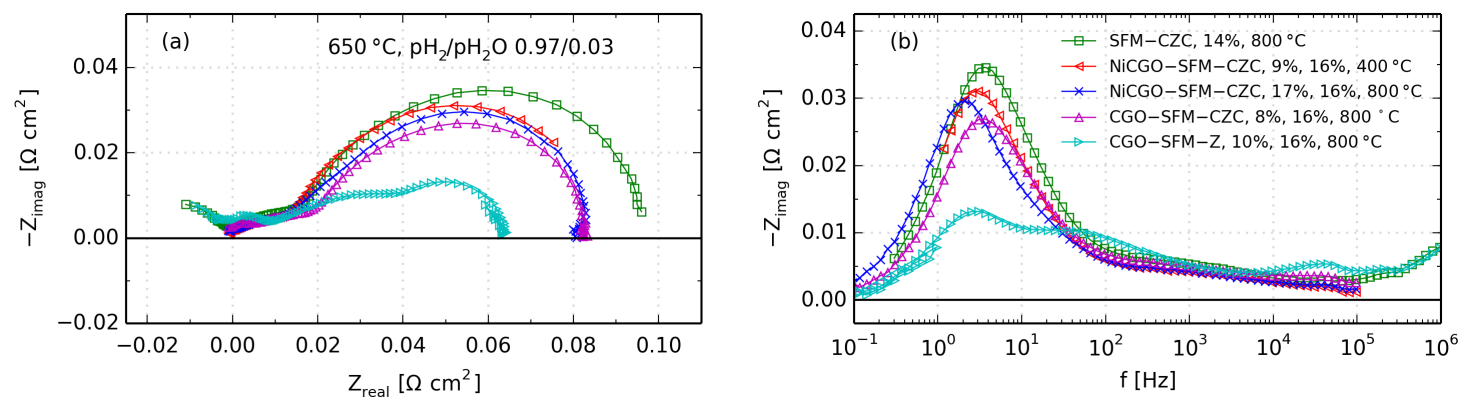

Figure 5. EIS data showing a comparison of different cell types. The approximate $\mathrm{R}_{\mathrm{s}}$ value has been subtracted and the symmetric cell data has been divided by 2 to ease comparison of $\mathrm{R}_{\mathrm{p}}$. Percentages and temperatures in the legend describe the approximate amount of infiltrated materials in vol- $\%$ and the calcination temperature after SFM infiltration, respectively.

$\mathrm{R}_{\mathrm{p}}$ could be even further reduced by increasing the thickness of the electrodes from $10 \mu \mathrm{m}$ to $18 \mu \mathrm{m}$ for cells of the type $\mathrm{Z}$ (Figure 5), suggesting that the electrochemically active volume of these cells extends further than $10 \mu \mathrm{m}(22-24)$. The " $Z$ " cells do not have barrier layers, which may eventually cause problems with formation of the low- 
conductivity phase strontium zirconate (25-27), but the initial $R_{p}$ should not be affected by this.

The decrease of $R_{s}$ after infiltrating SFM can be seen in the Arrhenius type plot of $R_{S}$ in Figure 6a. It is also seen that $R_{s}$ is not significantly affected by subsequently infiltrating NiCGO or CGO. It will be noticed that in this plot, $\mathrm{R}_{\mathrm{s}}$ of a non-infiltrated $\mathrm{Z}$ cell is compared to infiltrated CZC cells. The barrier layers of the CZC cells would slightly increase $R_{s}$ compared to the $Z$ cells, while the comparatively thinner CGO electrodes would decrease it. In any case, $R_{s}$ will mainly be caused by the thick electrolytes, which are identical for the two types. Thus, with this in mind it is deemed fair to directly compare $\mathrm{R}_{\mathrm{s}}$ of $\mathrm{Z}$ and CZC cells.

As expected, $R_{p}$ of the SFM infiltrated cell is slightly higher than the non-infiltrated cell, as seen in Figure $6 \mathrm{~b}$. However, the low $\mathrm{R}_{\mathrm{p}}$ of the non-infiltrated cell could be regained by subsequently infiltrating NiCGO or CGO on top of the infiltrated SFM.

Activation energies $\left(\mathrm{E}_{\mathrm{A}}\right)$ were calculated using equation 4 and 25 defined in Leonide et al. (28) for $R_{s}$ and $R_{p}$, respectively. $E_{A}\left(R_{s}\right)$ values were similar, approximately 78 $\mathrm{kJ} / \mathrm{mol}$, which agrees with values reported in literature for ScYSZ electrolytes (29). Activation energy for $\mathrm{R}_{\mathrm{p}}$ was $47.9 \mathrm{~kJ} / \mathrm{mol}$ for a $\mathrm{SFM}$ infiltrated cell, while it was slightly lower for cells that also has NiCGO or CGO infiltrated or does not have any infiltration (i.e. pure CGO), ranging from $35.7 \mathrm{~kJ} / \mathrm{mol}$ to $41.1 \mathrm{~kJ} / \mathrm{mol}$. It is noted that a stagnant gas layer on top of the cells in the used test setup causes a rather large contribution to $R_{p}(30-$ 32). This form of gas diffusion resistance is not inherent to the cells, and will artificially enlarge $R_{p}$. As gas diffusion resistance has a negligible activation energy (33), this also means that the $E_{A}\left(R_{p}\right)$ values reported here are artificially small.
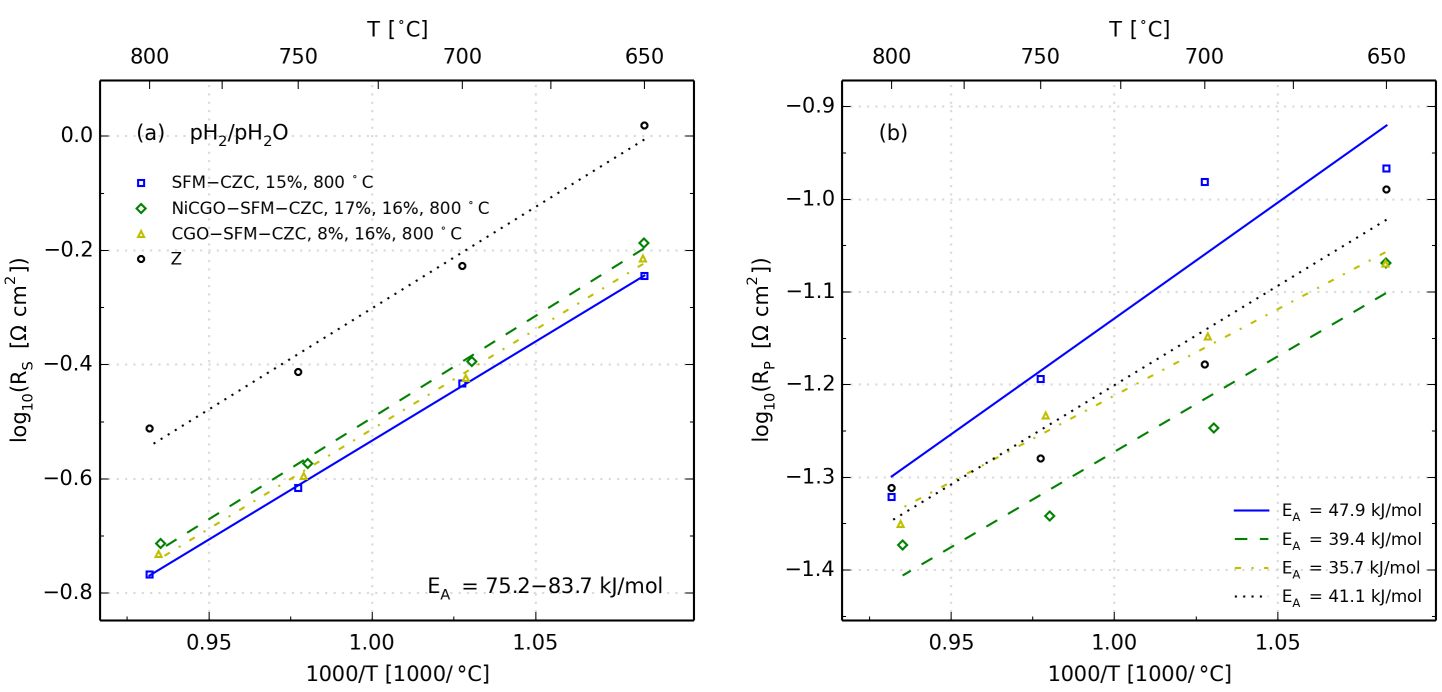

Figure 6. Arrhenius type plots of (a) $\mathrm{R}_{\mathrm{s}}$ and (b) $\mathrm{R}_{\mathrm{p}}$ in a $\mathrm{H}_{2} / \mathrm{H}_{2} \mathrm{O}$ atmosphere. $\log _{10}$ is used here for easier viewing, while $\mathrm{Ln}$ is used in the calculations. The percentages and temperatures in the legend have the same meanings as in previous figures. 
Varying $p \mathrm{O}_{2}$. The oxygen partial pressure was varied to investigate differences in performance at varying degrees of water content in the fuel gas. As seen in Figure 7a, the gain in conductivity when infiltrating SFM is again evident. The estimated theoretical ohmic resistance based on thickness of layers and conductivity of materials $(34,35)$ of the electrolyte and barrier layers is $0.17 \Omega \cdot \mathrm{cm}^{2}$ at $800{ }^{\circ} \mathrm{C}$. This represents the minimum ohmic resistance for these cells and is only possible if the electrodes are fully conducting. As can be seen, when infiltrating SFM or SM this minimum resistance is almost obtained and the electronic resistance of the electrodes is thus sufficiently low. Infiltrating NiCGO further lowers $\mathrm{R}_{\mathrm{s}}$ to approximately the estimated theoretical minimum. The polarization resistance of the cells, as seen in Figure $7 \mathrm{~b}$, finds a minimum at approximately $p \mathrm{H}_{2} \mathrm{O}=$ $0.17\left(p \mathrm{O}_{2}=2 \cdot 10^{-20} \mathrm{~atm}\right)$ and once again the lower $\mathrm{R}_{\mathrm{p}}$ of cells with CGO covering the active surface is observed. Thus, the surface blocking effect of SFM or SM is evident. It is seen that SFM is approximately equal to $S M$ regarding $R_{s}$, but superior in terms of electro-catalytic capabilities.
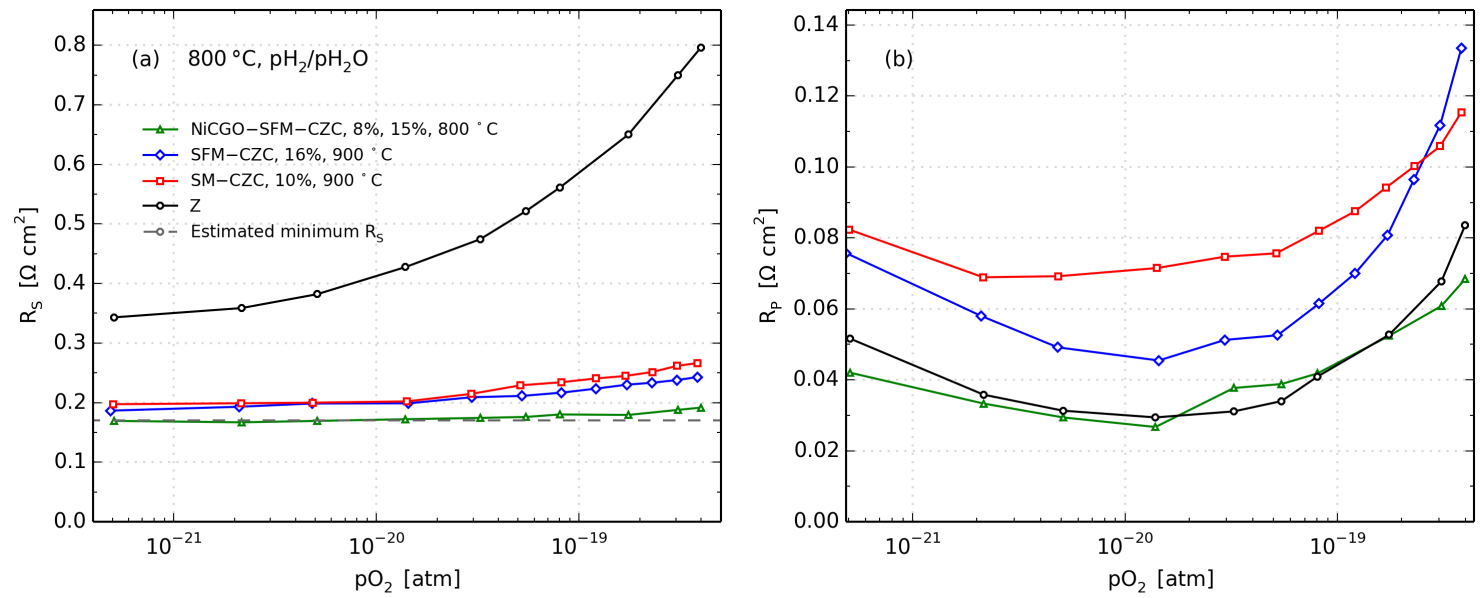

Figure 7. (a) $\mathrm{R}_{\mathrm{s}}$ and (b) $\mathrm{R}_{\mathrm{p}}$ against $p \mathrm{O}_{2}$ in a $\mathrm{H}_{2} / \mathrm{H}_{2} \mathrm{O}$ atmosphere at $800{ }^{\circ} \mathrm{C}$ for different cell types. The $p \mathrm{O}_{2}$ is estimated from the Nernst equation. The points represent $p \mathrm{H}_{2} \mathrm{O}=$ $0.03,0.07,0.10,0.17,0.23,0.30,0.37,0.43,0.50,0.57,0.63$ and 0.70 from left to right. The percentages and temperatures in the legend have the same meanings as in previous figures.

Comparing with literature. The best performing cells have an $\mathrm{R}_{\mathrm{p}}$ of $0.07-0.10 \Omega \cdot \mathrm{cm}^{2}$ at $650{ }^{\circ} \mathrm{C}$ and $0.04 \Omega \cdot \mathrm{cm}^{2}$ at $800{ }^{\circ} \mathrm{C}$ in a $p \mathrm{H}_{2} / p \mathrm{H}_{2} \mathrm{O}$ atmosphere of $0.97 / 0.03$ (close to $0.02 \Omega \cdot \mathrm{cm}^{2}$ in $\left.p \mathrm{H}_{2} / p \mathrm{H}_{2} \mathrm{O}=0.83 / 0.17\right)$. $\mathrm{R}_{\mathrm{s}}$ of the electrodes is difficult to estimate due to contributions from the electrolyte and barrier layers, but based on the previously discussed estimations, it is close to zero. To the best of the authors' knowledge, these $R_{p}$ values are among the best reported for symmetric cell measurements. In the same conditions at $650{ }^{\circ} \mathrm{C}$, Blennow et al. have reported values for state-of-the-art NiCGO infiltrated Nb-doped $\mathrm{SrTiO}_{3}$ backbones of $0.20 \Omega \cdot \mathrm{cm}^{2}(14)$ and a NiCGO infiltrated FeCr-YSZ (Risø 3G) cell of $0.12 \Omega \cdot \mathrm{cm}^{2}$ (14). Ramos et al. reported a single electrode $\mathrm{R}_{\mathrm{p}}$ for Ni-ScYSZ electrodes with electrolyte support (similar to the cells presented here) of $0.28 \Omega \cdot \mathrm{cm}^{2}$, however at $750{ }^{\circ} \mathrm{C}$, but in the same gas atmosphere (19), where gas diffusion resistance had also been estimated and subtracted (not done for the present 
study). Ramos et al. also reported $0.14 \Omega \cdot \mathrm{cm}^{2}$ for a Ni-ScYSZ electrode in an electrodesupported symmetric cell at the same conditions at $750{ }^{\circ} \mathrm{C}$. For Ni-infiltrated $\mathrm{La}_{1-\mathrm{x}}$ $\mathrm{Sr}_{\mathrm{x}} \mathrm{Ga}_{0.8} \mathrm{Mg}_{0.2} \mathrm{O}_{3-\delta}$ electrodes in $p \mathrm{H}_{2} / p \mathrm{H}_{2} \mathrm{O}$ of $0.97 / 0.03$, Miller et al. reported $0.08 \Omega \cdot \mathrm{cm}^{2}$ at $550{ }^{\circ} \mathrm{C}(36)$, and Zhan et al. reported a very low $0.014 \Omega \cdot \mathrm{cm}^{2}$ at $550{ }^{\circ} \mathrm{C} \mathrm{(37).} \mathrm{Graves} \mathrm{et}$ al. reported $0.10 \Omega \cdot \mathrm{cm}^{2}$ at $750{ }^{\circ} \mathrm{C}$ for Ni-YSZ, but in $p \mathrm{H}_{2} / p \mathrm{H}_{2} \mathrm{O} 0.50 / 0.50$ (38). Unlike the cells presented in this study, all of the mentioned cells have used $\mathrm{Ni}$ to enhance the electro-catalytic activity and are thus prone to carbon formation.

Performance in $\mathrm{CO} / \mathrm{CO}_{2}$. The performance in $\mathrm{H}_{2} / \mathrm{H}_{2} \mathrm{O}$ is compared to that in $\mathrm{CO} / \mathrm{CO}_{2}$, again at varying degrees of $\mathrm{pO}_{2}$. Both for the non-infiltrated cell and the infiltrated cells, it appears that the performance difference between $\mathrm{H}_{2} / \mathrm{H}_{2} \mathrm{O}$ and $\mathrm{CO} / \mathrm{CO}_{2}$ is minimal, in regards to $\mathrm{R}_{\mathrm{s}}$ (Figure 8a). However, the difference is more pronounced regarding $\mathrm{R}_{\mathrm{p}}$ (Figure 8b), being about 2-4 times higher in $\mathrm{CO} / \mathrm{CO}_{2}$ than in $\mathrm{H}_{2} / \mathrm{H}_{2} \mathrm{O}$. This ratio is similar to $\mathrm{CGO}$ porous electrode data published by Graves et al. (38). $\mathrm{R}_{\mathrm{p}}$ in a $p \mathrm{CO} / p \mathrm{CO}_{2}$ atmosphere of $0.50 / 0.50$ is approximately $0.23 \Omega \cdot \mathrm{cm}^{2}$, comparable to $0.20 \Omega \cdot \mathrm{cm}^{2}$ reported for state-of-the-art Ni-YSZ (38). However, the microstructure of the latter cells has been highly optimized, contrary to the CGO10 backbone reported here.
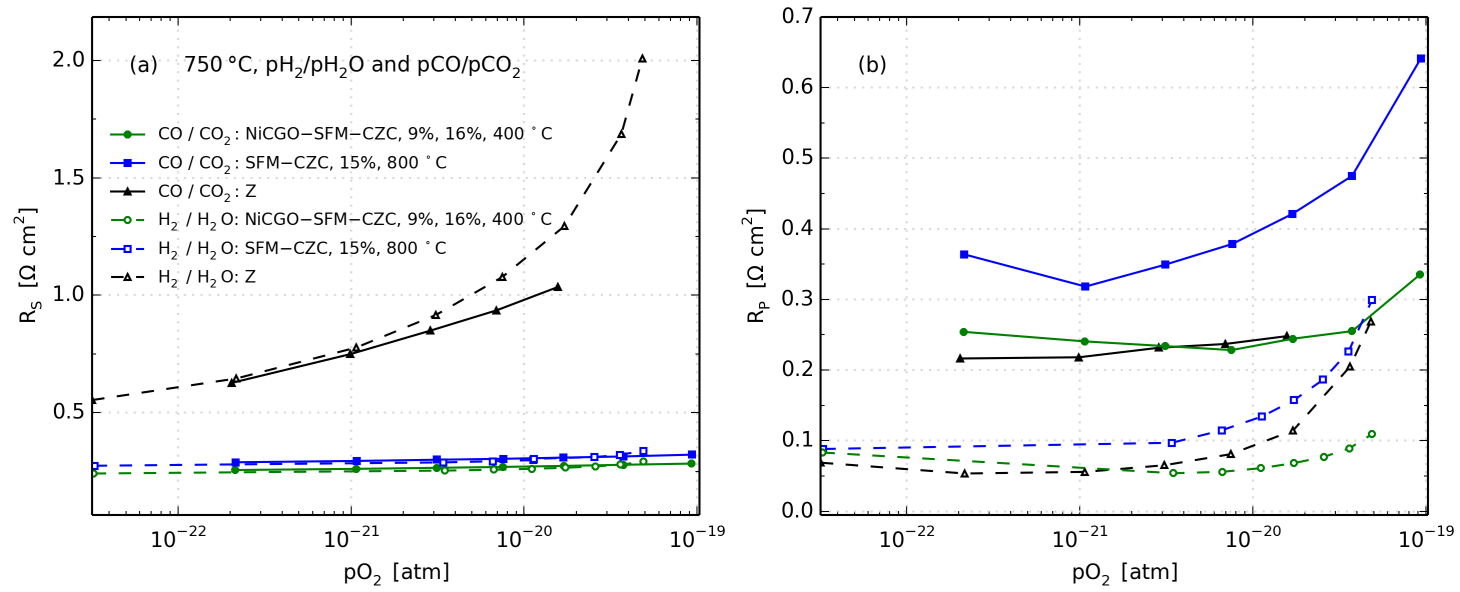

Figure 8. Comparison of performance in $\mathrm{CO} / \mathrm{CO}_{2}$ to $\mathrm{H}_{2} / \mathrm{H}_{2} \mathrm{O}$ at $750{ }^{\circ} \mathrm{C}$ for three different cell types. The points represent $p \mathrm{H}_{2} \mathrm{O}=0.03,0.30,0.40,0.50,0.60,0.70,0.80,0.90$ or $p \mathrm{CO}_{2}=0.10,0.20,0.30,0.40,0.50,0.60,0.70$ from left to right, except for cell $\mathrm{Z}$ for which the points represent $p \mathrm{H}_{2} \mathrm{O}=0.03,0.08,0.18,0.29,0.42,0.60,0.81,0.90$ and $p \mathrm{CO}_{2}$ $=0.10,0.20,0.30,0.40,0.50$. The percentages in the legend have the same meanings as in previous figures.

Carbon deposition. The investigation was carried out in what can be considered an idealized atmosphere for testing carbon deposition, namely $\mathrm{CO} / \mathrm{CO}_{2}$, where the Boudouard reaction, $2 \mathrm{CO} \leftrightarrow \mathrm{C}+\mathrm{CO}_{2}$ is easily controlled. The cells were exposed to varying degrees of $\mathrm{CO} / \mathrm{CO}_{2}$, and in-between each step ( $\sim 2 \mathrm{~h}$ each) the performance in $\mathrm{H}_{2} / \mathrm{H}_{2} \mathrm{O}$ was checked. The plots in Figure 9 therefore show the performance in $\mathrm{H}_{2} / \mathrm{H}_{2} \mathrm{O}$ after being exposed to varying degrees of $\mathrm{CO}$ in $\mathrm{CO}_{2}$. This was done to investigate the possible damage being done to the cells after being in an atmosphere with a carbon activity greater than 1 . The theoretical carbon deposition (Boudouard) threshold, above which carbon will deposit, is $p \mathrm{CO} / p \mathrm{CO}_{2}=0.784 / 0.216$ at this temperature $\left(750{ }^{\circ} \mathrm{C}\right)$. As 
can be seen in Figure 9a, $\mathrm{R}_{\mathrm{s}}$ is not affected for any of the cells, except the one containing NiCGO after the $p \mathrm{CO} / p \mathrm{CO}_{2}=0.90 / 0.10$ step. Likewise, $\mathrm{R}_{\mathrm{p}}$ was only affected for the $\mathrm{NiCGO}$ containing cell at $p \mathrm{CO} / p \mathrm{CO}_{2}=0.90 / 0.10$ (Figure $9 \mathrm{~b}$ ).
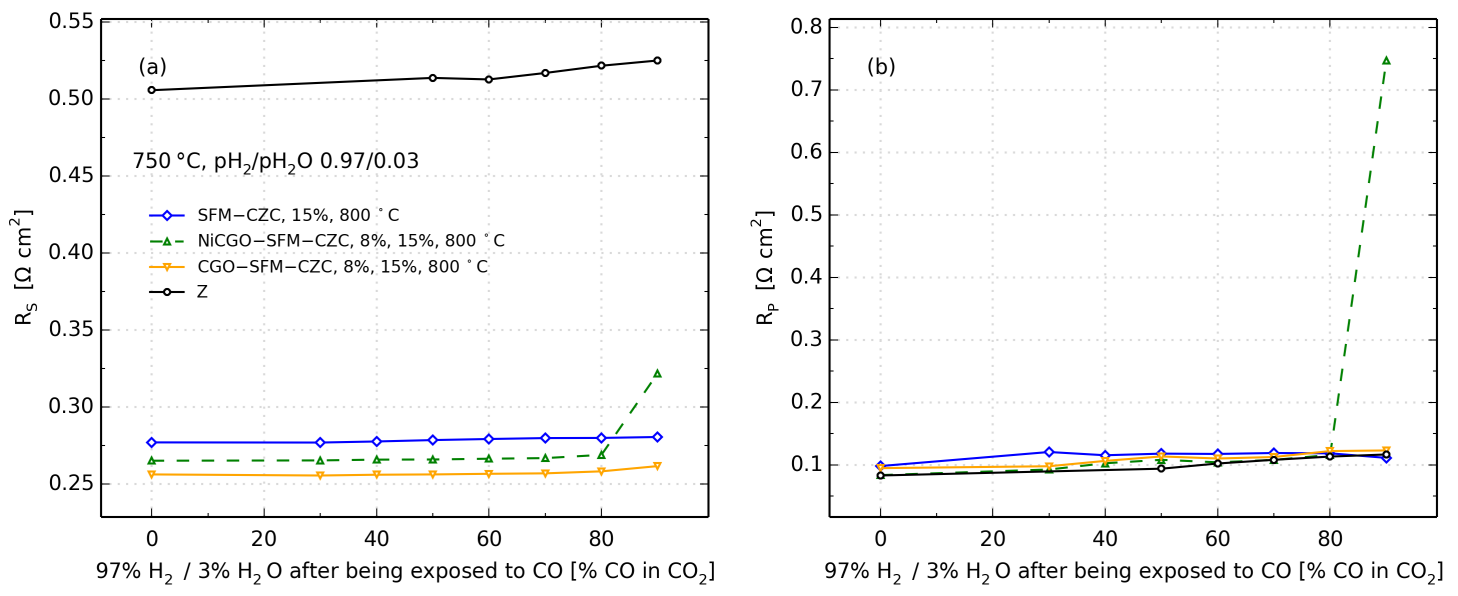

Figure 9. (a) $\mathrm{R}_{\mathrm{s}}$ and (b) $\mathrm{R}_{\mathrm{p}}$ for different cell types in hydrogen with $3 \% \mathrm{H}_{2} \mathrm{O}$ at $750{ }^{\circ} \mathrm{C}$ after being exposed to different amounts of $\mathrm{CO}$ in $\mathrm{CO}_{2}$, ranging from $0 \%$ to $30 \%, 40 \%$, $50 \%, 60 \%, 70 \%, 80 \%$ and lastly $90 \% \mathrm{CO}$ in $\mathrm{CO}_{2}$. The percentages in the legend have the same meanings as in previous figures.

Because of the apparent carbon deposition only at $90 \% \mathrm{CO}$ in $\mathrm{CO}_{2}$ and not at the expected $80 \% \mathrm{CO}$ in $\mathrm{CO}_{2}$, it was speculated that the carbon deposition was not instantaneous, but occurred gradually with time. The time effect of carbon deposition is known from catalysis research (39). To investigate this phenomenon in greater detail the cells were left in an atmosphere that would surely cause coking for $15 \mathrm{~h}\left(p \mathrm{CO} / p \mathrm{CO}_{2}=\right.$ $0.90 / 0.10)$. The performance can be seen in Figure 10, note that now the data is for a $\mathrm{CO} / \mathrm{CO}_{2}$ atmosphere. For the NiCGO containing cells, $\mathrm{R}_{\mathrm{p}}$ increases gradually over the course of $15 \mathrm{~h}$ in $\mathrm{CO} / \mathrm{CO}_{2}$ indicating carbon deposition, whereas for the Ni-free cells $\mathrm{R}_{\mathrm{p}}$ was very stable. Interestingly, $\mathrm{R}_{\mathrm{s}}$ is not affected for the NiCGO containing cells in $\mathrm{CO} / \mathrm{CO}_{2}$, but as seen in Figure $9 \mathrm{a}$, it was when switching back to $\mathrm{H}_{2} / \mathrm{H}_{2} \mathrm{O}$. It is speculated that the carbon is facilitating the electronic conduction and upon gas change to $\mathrm{H}_{2} / \mathrm{H}_{2} \mathrm{O}$, the carbon is oxidized leaving a less electronically percolating network. Thus, $\mathrm{R}_{\mathrm{s}}$ is increased as seen in Figure 9a. Because of the underlying electronically conducting SFM layer, the increase in $\mathrm{R}_{\mathrm{s}}$ observed in $\mathrm{H}_{2} / \mathrm{H}_{2} \mathrm{O}$ is limited, however, compared to the increase in $R_{p}$. This hypothesis should be investigated in the future.

All cells that indicated carbon deposition during the tests (only NiCGO containing cells) had their electrodes completely covered in black carbon dust when viewed posttesting (not shown). This may be carbon fibers growing up through the pores in the Pt contacting layer. This also shows that the Pt-contact layer used for all cells does not appreciably catalyze carbon deposition. 

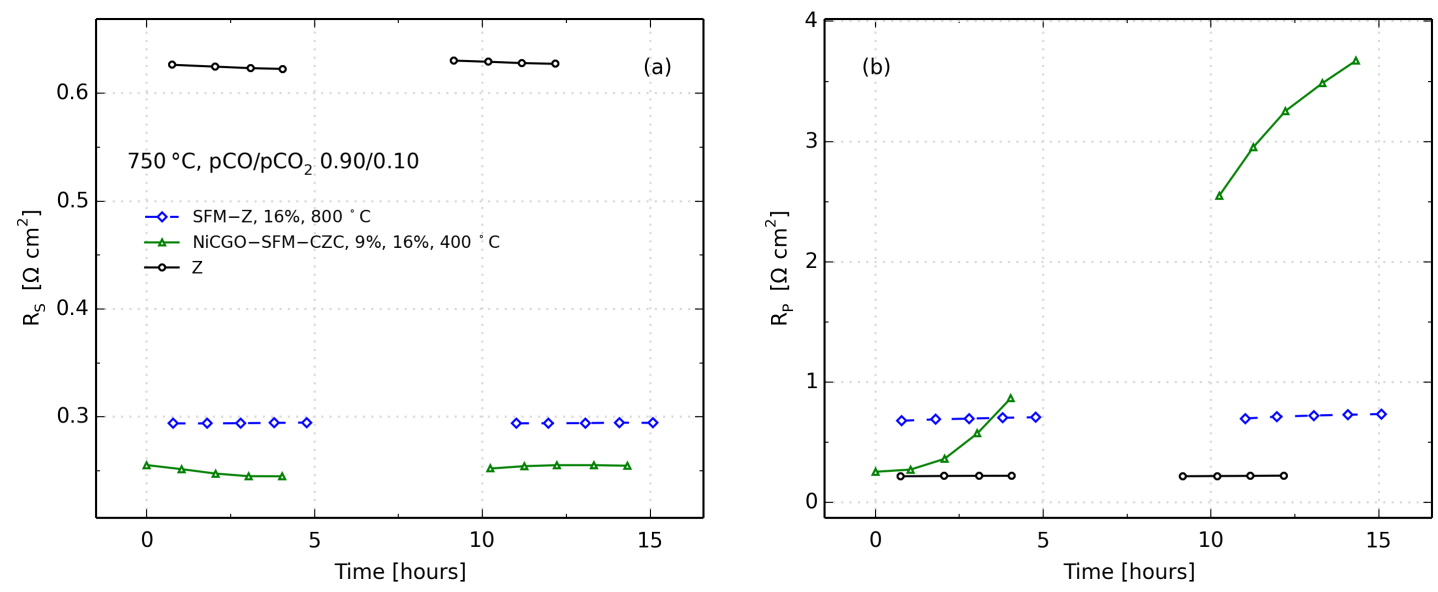

Figure 10. (a) $\mathrm{R}_{\mathrm{s}}$ and (b) $\mathrm{R}_{\mathrm{p}}$ for $15 \mathrm{~h}$ in a $p \mathrm{CO} / p \mathrm{CO}_{2}$ atmosphere of $0.90 / 0.10$ at $750{ }^{\circ} \mathrm{C}$ for different cell types. The percentages in the legend have the same meanings as in previous figures.

Redox stability. It was attempted to reactivate the coked NiCGO infiltrated cells with long-term exposure to a $\mathrm{H}_{2} / \mathrm{H}_{2} \mathrm{O}$ atmosphere and performing redox cycles. Both strategies proved unsuccessful as the damage was irreversible and was dramatically worsened by the redox cycles. Cells that did not contain nickel and had therefore not coked, were also exposed to such a treatment. The two redox cycles at $650{ }^{\circ} \mathrm{C}$ and $750{ }^{\circ} \mathrm{C}$ did not affect $\mathrm{R}_{\mathrm{s}}$ and actually reduced $\mathrm{R}_{\mathrm{p}}$ by $18 \%$ for the CGO-SFM-CZC type cell, an activation phenomenon not uncommon for oxide electrodes (40). The cells thus indicate stability towards redox cycles.

\section{Conclusions}

A novel fuel electrode design was developed and tested. A CGO10 backbone infiltrated with SFM and CGO20 was utilized, each layer mainly supplying ionic conductivity, electronic conductivity or electro-catalytic activity, respectively. A backbone of high porosity was used to enable high loadings of infiltrated materials with high surface area. Preliminary electrochemical symmetric cell testing indicated neglible electronic resistance and polarization resistance lower than alternative state-of-the-art fuel electrodes. Compared with the porous $\mathrm{CGO}$ electrodes, the electrode performance was greatly improved; at $650{ }^{\circ} \mathrm{C}$ in $p \mathrm{H}_{2} / p \mathrm{H}_{2} \mathrm{O} 0.97 / 0.03, \mathrm{R}_{\mathrm{s}}$ of the electrodes decreased from $\sim 0.26 \Omega \mathrm{cm}^{2}$ to close to zero, while $\mathrm{R}_{\mathrm{p}}$ could also be lowered from $0.10 \Omega \mathrm{cm}^{2}$ to $0.06 \Omega \mathrm{cm}^{2}$, including diffusion resistance from a large stagnant gas layer inherent to the test setup. Furthermore, the electrodes showed excellent stability in a high carbon activity $\mathrm{CO} / \mathrm{CO}_{2}$ gas mixture and through redox cycles - conditions that cause detrimental degradation of conventional Ni-based fuel electrode materials. The fuel electrode design strategy and the chosen materials are thus promising candidates as alternatives to the traditional Ni-YSZ composite. 


\section{Acknowledgments}

Financial support from the EU project METSAPP (FP7-278257), The Danish National Advanced Technology Foundation, and from Energinet.dk under the ForskEL project 2014-1-12231 is gratefully acknowledged. The authors would like to thank colleagues at DTU Energy for technical assistance and fruitful discussions: T. Ramos, S. Veltzé, A. Hauch, A. Mikkelsen, P. H. Nielsen, K. Thydén, E. Abdellahi, J. Bentzen, H. Paulsen, J. Nielsen and M. Mogensen.

\section{References}

1. P. E. Morthorst, L. H. Nielsen, and L. Schleisner, Hydrogen as an energy carrier, (1993).

2. I. Alstrup, M. T. Tavares, C. a Bernardo, O. Sørensen, and J. R. Rostrup-Nielsen, Mat. Corros., 49, 367-372 (1998).

3. C. Chatzichristodoulou, P. T. Blennow, M. Søgaard, P. V. Hendriksen, and M. B. Mogensen, in Catalysis by Ceria and Related Materials, 623-782 (2013).

4. Q. Liu, X. Dong, G. Xiao, F. Zhao, and F. Chen, Adv. Mater., 22, 5478-5482 (2010).

5. Q. Liu, C. Yang, X. Dong, and F. Chen, Int. J. Hydrogen Energy, 35, 10039-10044 (2010).

6. B. He et al., J. Electrochem. Soc., 159, B619-B626 (2012).

7. Q. Liu, G. Xiao, T. Howell, T. L. Reitz, and F. Chen, Electrochem. Soc., 35, 1357$1366(2011)$.

8. Z. Wang, Y. Tian, and Y. Li, J. Power Sources, 196, 6104-6109 (2011).

9. L. Zhang, Q. Zhou, Q. He, and T. He, J. Power Sources, 195, 6356-6366 (2010).

10. C. Graves, B. R. Sudireddy, and M. Mogensen, ECS Trans., 28, 173-192 (2010).

11. G. Xiao et al., J. Power Sources, 202, 63-69 (2012).

12. L. Zhang et al., Electrochem. commun., 13, 711-713 (2011).

13. G. Xiao, Q. Liu, S. Nuansaeng, and F. Chen, ECS Trans., 45, 355-362 (2012).

14. P. Blennow, Ph.d. thesis (2007).

15. P. Plonczak et al., J. Power Sources, 196, 1156-1162 (2011).

16. T. Ramos et al., Fuel Cells, 14, 1062-1065 (2014).

17. W. S. Rasband, Image J version 1.46r.

18. Bruker Difrac Plus Eva, see more at http://www.bruker.com. 
19. T. Ramos, K. Thydén, and M. Mogensen, ECS Trans., 28, 123-139 (2010).

20. C. Graves, RAVDAV data analysis software, version 0.9.8 (2015).

21. G. Xiao et al., J. Electrochem. Soc., 158, B455-B460 (2011).

22. J. Nielsen, T. Klemensø, and P. Blennow, J. Power Sources, 219, 305-316 (2012).

23. J. Nielsen, T. Jacobsen, and M. Wandel, Electrochim. Acta, 56, 7963-7974 (2011).

24. J. Nielsen and J. Hjelm, Electrochim. Acta, 115, 31-45 (2014).

25. H. Yokokawa, Solid State Ionics, 40-41, 398-401 (1990).

26. C. Clausen, C. Bagger, J. Bildesorensen, and A. Horsewell, Solid State Ionics, 70-71, 59-64 (1994).

27. Y. L. Liu et al., Solid State Ionics, 180, 1298-1304 (2009).

28. A. Leonide, Y. Apel, and E. Ivers-Tiffee, ECS Trans., 19, 81-109 (2009).

29. T. Ramos and S. Veltzé, ECS Electrochem. Lett., 3, F5-F6 (2014).

30. S. Primdahl and M. Mogensen, J. Electrochem. Soc., 146, 2827 (1999).

31. A. Mohammed Hussain, J. V. T. Høgh, T. Jacobsen, and N. Bonanos, Int. J. Hydrogen Energy, 37, 4309-4318 (2012).

32. T. Ramos, M. Sogaard, and M. B. Mogensen, J. Electrochem. Soc., 161, F434-F444 (2014).

33. S. Primdahl and M. Mogensen, J. Electrochem. Soc., 146, 2827 (1999).

34. S. Omar, W. Bin Najib, W. Chen, and N. Bonanos, B. Dunn, Editor. J. Am. Ceram. Soc., 95, 1965-1972 (2012).

35. S. Wang, T. Kobayashi, M. Dokiya, and T. Hashimoto, J. Electrochem. Soc., 147, 3606-3609 (2000).

36. E. C. Miller, Q. Sherman, Z. Gao, P. W. Voorhees, and S. A. Barnett, ECS Trans., 68, 1245-1254 (2015).

37. Z. Zhan et al., RSC Adv., 2, 4075 (2012).

38. C. Graves, C. Chatzichristodoulou, and M. Mogensen, Faraday Discuss., 182, 75-95 (2015).

39. M. T. Tavares, I. Alstrup, and C. a Bernardo, J. Catal., 410, 402-410 (1996).

40. J. T. S. Irvine et al., Nat. Energy, 1, 15014 (2016). 